\title{
Soil warming effect on net ecosystem exchange of carbon dioxide during the transition from winter carbon source to spring carbon sink in a temperate urban lawn
}

\author{
Xiaoping Zhou ${ }^{1,2}$, Xiaoke Wang ${ }^{1, *}$, Lei Tong ${ }^{1}$, Hongxing Zhang ${ }^{1}$, Fei Lu ${ }^{1}$, Feixiang Zheng ${ }^{1}$, \\ Peiqiang Hou ${ }^{1}$, Wenzhi Song ${ }^{1}$, Zhiyun Ouyang ${ }^{1}$ \\ 1. Research Center for Eco-Environmental Sciences, Chinese Academy of Sciences, Beijing 100085, China. E-mail: xiaopingzh2005@126.com \\ 2. Graduate School of Chinese Academy of Sciences, Beijing 100039, China
}

Received 06 February 2012; revised 20 March 2012; accepted 01 April 2012

\begin{abstract}
The significant warming in urban environment caused by the combined effects of global warming and heat island has stimulated widely development of urban vegetations. However, it is less known of the climate feedback of urban lawn in warmed environment. Soil warming effect on net ecosystem exchange (NEE) of carbon dioxide during the transition period from winter to spring was investigated in a temperate urban lawn in Beijing, China. The NEE (negative for uptake) under soil warming treatment (temperature was about $5^{\circ} \mathrm{C}$ higher than the ambient treatment as a control) was $-0.71 \mu \mathrm{mol} /\left(\mathrm{m}^{2} \cdot \mathrm{sec}\right)$, the ecosytem was a $\mathrm{CO}_{2}$ sink under soil warming treatment, the lawn ecosystem under the control was a $\mathrm{CO}_{2}$ source $\left(0.13 \mu \mathrm{mol} /\left(\mathrm{m}^{2} \cdot \mathrm{sec}\right)\right)$, indicating that the lawn ecosystem would provide a negative feedback to global warming. There was no significant effect of soil warming on nocturnal NEE (i.e., ecosystem respiration), although the soil temperature sensitivity $\left(Q_{10}\right)$ of ecosystem respiration under soil warming treatment was 3.86 , much lower than that in the control (7.03). The $\mathrm{CO}_{2}$ uptake was significantly increased by soil warming treatment that was attributed to about $100 \%$ increase of $\alpha$ (apparent quantum yield) and $A_{\max }$ (maximum rate of photosynthesis). Our results indicated that the response of photosynthesis in urban lawn is much more sensitive to global warming than respiration in the transition period.
\end{abstract}

Key words: soil warming; urban lawn; $\mathrm{CO}_{2}$ uptake; ecosystem respiration

DOI: $10.1016 / \mathrm{S} 1001-0742(11) 61057-7$

\section{Introduction}

With increasing atmospheric $\mathrm{CO}_{2}$ concentration, the global temperature would be predicted to rise at very high confidence level (IPCC, 2007). Terrestrial ecosystems, as one of the global largest carbon storages (IPCC, 2000), could significantly regulate the atmospheric $\mathrm{CO}_{2}$ content through net ecosystem exchange (NEE) of $\mathrm{CO}_{2}$. Not only would the future climate change depend on anthropogenic carbon emissions, but also on carbon emission in terrestrial ecosystems. Since the photosynthesis and respiration respond differently to change in temperature, there would be strong feedback between global warming and carbon cycle of terrestrial ecosystem (Delpierre et al., 2009; Huxman et al., 2003; Lafleur and Humphreys, 2008).

The feedback of vegetation to climate in the changing global climate is one of the important contents of the global change studies (Yu et al., 2010). Previous studies have reported that autotrophic respiration is more sensitive than photosynthesis to increases in temperature (Ryan, 1991; Amthor, 1994). Yin et al. (2008) reported that the photo-

\footnotetext{
* Corresponding author. E-mail: wangxk@rcees.ac.cn
}

synthetic capacity of Picea asperata and Abies faxoniana seedlings was increased by warming, and the warming was beneficial to the seedling growth and development during the early growing season. Many models also predict autotrophic respiration will increase at a greater rate than photosynthesis, which implies a substantial increase in temperature could stimulate carbon emission from terrestrial ecosystems or turn terrestrial ecosystems from a carbon sink to a carbon source (Vemap et al., 1995; Ryan et al., 1995, 1996; Goulden et al., 1998). However, a recent study reported that there was not significant changes in the rates of light-saturated net photosynthesis, foliage respiration and stem respiration in boreal black spruce ecosystem under heating treatments in a 3-years experiment, which does not support the early investigation and modeling results (Bronson and Gower, 2010). With climate warming, ecosystem photosynthesis will start early that would increase carbon uptake. Baldocchi and Wilson (2001) have reported that, across a range of temperate deciduous sites, a one-day increase in growing season length (as defined by the number of days between sourcesink transition in the spring and sink-source transition in the autumn) increased annual net ecosystem productivity 
(NEP) by $5.7 \mathrm{~g} \mathrm{C} / \mathrm{m}^{2}$. Therefore, more field experiments are necessary to investigate the temporal variations in photosynthesis and respiration of terrestrial ecosystem under climate change, especially in period of ecosystem recovery from the dormant period.

The measurements of NEE have mostly focused on the growing season because of higher flux rates. Only a few studies have been done during dormant or low temperature periods. In last decade, some field measurements have showed that small but continuous rates of ecosystem respiration during the winter can significantly influence the annual carbon balance in seasonal forests (Hubbard et al., 2005). The NEE in the transition period from winter to spring has also been paid to more attention in recent years (Lafleur and Humphreys, 2008; Welker et al., 2004; Keeling, 1996). Climate change in early spring could determine the timing of carbon switch from source to sink. For instance, soil thaw-freeze cycles in transition from winter to spring influence ecosystem NEE due to rapid changes in soil moisture condition. The climate change in this transition period would exert an important control over the seasonal variation of NEE (Law et al., 2000; Lloyd et al., 2002; Monson et al., 2002; Huxman et al., 2003; Tanja et al., 2003; Ensminger et al., 2004). Monson et al. (2005) reported that interannual variation in the annual cumulative NEE was mostly explained by variation in NEE during the snow-melt period in subalpine forest. Therefor, it is important to investigate the carbon cycle in the transition period in response to climate change, including global warming.

With the rapid urbanization, half of the world's population has lived on urban areas (World Resources Institute, 1996). Large area of forest, grassland and arable land is annually being lost to the expansion of urban area. Meanwhile, with urban development, urban lawn, a kind of greenlands, is increasing in parks, communities, commercial landscapes, recreational facilities, golf courses, and other greenlands. For example, in Beijing and Shanghai of China, about $115 \mathrm{~km}^{2}$ land is annually being changed to lawn (Lao, 2002). Some studies had carried out to investigate the $\mathrm{CO}_{2}$ exchange in urban greenland area (Allaire et al., 2008).

Since vegetations are capable of providing multiple ecological services for urban society, e.g., direct shading and indirect evapotranspiration for alleviating heat island effect, conservation of stormwater for reducing flooding, biodiversity conservation, and aesthetic value, the effects of climate change on urban vegetations need to be investigated (Teodorescu, 2010). For example, Mimet et al. (2009) studied the response of flowering time of Platanus acerifolia and Prunus cerasus to the temperature change induced by the urbanization. Carbon sequestration, one of important ecological service of urban vegetation, has been receiving more attention with global concerning climate change and carbon cycle. Qian and Follet (2002) estimated the carbon sequestration rate in urban lawn was about 1 $\mathrm{Mg}$ (ha.year). Ranajit (2008) suggested that well managed lawns sequester, or store, significant amounts of carbon, and the healthy turf grass can capture up to $1.49 \mathrm{Mg}$
$\mathrm{C} /$ (ha.year). In the future, urban land would be stressed by global warming induced by the rise of atmospheric greenhouse gases and intensified urban heat island. It is still not clear how the carbon cycle of urban lawn would respond to climate change.

In this study, NEE of urban lawn were measured by automated chamber system in a paired comparison experiment with heating and no heating treatments. The aims are to investigate: (1) the changes in NEE of urban lawn during the transition period from winter to spring, (2) the feedback between NEE of urban lawn and soil warming, (3) the different responses of ecosystem respiration and photosynthesis to soil warming.

\section{Materials and methods}

\subsection{Experimental site}

The experiment was conducted in the Educational Arboretum of Beijing, located in downtown area of Beijing $\left(116^{\circ} 25^{\prime} 37^{\prime \prime} \mathrm{E}, 39^{\circ} 52^{\prime} 28^{\prime \prime} \mathrm{N}\right)$. The climate belongs to the temperate monsoon climate. The annual mean temperature is $11^{\circ} \mathrm{C}$ with range of $-20^{\circ} \mathrm{C}$ and $40^{\circ} \mathrm{C}$, and the annual precipitation is about $500 \mathrm{~mm}$. Approximately $80 \%$ of the precipitation occurred in summer and autumn.

The lawn of turf grass (Zoysia japonica Steud.) was located in the center of the Educational Arboretum, managed as normal practices without drought stress and fertilized two times a year, one in middle of March $(45 \mathrm{~kg} / \mathrm{ha}$ mineral $\mathrm{N}, 6 \mathrm{~kg} / \mathrm{ha}$ phosphorus and $3 \mathrm{~kg} /$ ha potassium) and another in November before the soil was frozen $(40 \mathrm{~kg} / \mathrm{ha}$ mineral $\mathrm{N}, 6 \mathrm{~kg} / \mathrm{ha}$ phosphorus and $2 \mathrm{~kg} / \mathrm{ha}$ potassium). The grass was mowed at interval of 2-3 weeks in summer and early fall. The soils were sampled on 15-Dec-2009 to measure the soil property. The soil organic carbon, nitrite and ammonium nitrogen were $18.3 \mathrm{mg} / \mathrm{g}, 6.30 \mu \mathrm{g} / \mathrm{g}, 1.59$ $\mu \mathrm{g} / \mathrm{g}$ respectively, and $\mathrm{pH}$ was 7.2.

\subsection{Experimental design}

The soil warming was achieved by burying heating pipes at $50 \mathrm{~cm}$ depth of the lawn (soil warming). The neighboring plot without soil warming was set as the control. The pipes connected the heating system which supports office heating during 15-Jan-2010 to 30-Mar-2010. Four automated chambers were installed in each plot as the replications. The chambers were inserted $6 \mathrm{~cm}$ deep into soil to ensure gas tightness.

\section{3 $\mathrm{CO}_{2}$ flux measurement}

The NEE was measured with an automated multi-channel chamber system. The chambers were installed on 15 -Dec2009. The automated chambers $(50 \mathrm{~cm} \times 50 \mathrm{~cm} \times 50 \mathrm{~cm}$, length $\times$ width $\times$ height) had walls made from transparent PVC glued and fixed to the aluminum alloy and had lids hinged at the sidewalls. The high-density rubber gaskets were glued to the upper edge of the chambers for tight closing. A small fan within each chamber was used for mixing the air when the lid was closed. A tube with inner diameter of $4 \mathrm{~mm}$ and length of $1.5 \mathrm{~m}$ was inserted through 
the lid of each chamber to maintain the pressure inside the chamber near the ambient air when chamber was closed (Griffis et al., 2004). A cylinder was positioned within each chamber and driven by high pressure from a compressor to control the chamber lid open and close. Air sample was pumped from one chamber closed to pass through a multi-channel valve, the buffer tube, the desiccant tube, the filter, the flow controller into IRGA (Li-820, Li-Cor Inc., Lincoln, NE, USA) for measuring $\mathrm{CO}_{2}$ concentration within the chamber, and then returned the chamber. A Programmable Logical Controller (Master-K120S, LG, Korea) was deployed to control a series of solenoid valves to control the target chamber open and close, and air gas sample from and return to the target chamber. Each chamber was closed for $3 \mathrm{~min}$ (Drewitt et al., 2002) for the measurement. The flow rate was controlled at $1 \mathrm{~L} / \mathrm{min}$. The $\mathrm{CO}_{2}$ concentrations were monitored continuously by the IRGA and recorded at the interval of $10 \mathrm{sec}$ with a data logger (CR1000, Campbell Scientific Inc., Logan, UT, USA).

\subsection{Environmental measurement}

Copper-constantan thermocouples were used to measure the soil temperature at the depth of $5 \mathrm{~cm}$ near each chamber and air temperature inside chamber. Photosynthetic photon flux density (PPFD, 400-700 nm wave bands) was measured with Quantum Sensor (LI-190SA, Li-Cor Inc., Lincoln, NE, USA). The air and soil temperatures and photosynthetic active radiation (PAR) were recorded at an interval of $3 \mathrm{~min}$ in the data logger. The ambient air temperature and air pressure data were derived from meteorological station $300 \mathrm{~m}$ south of the plots which was managed by Beijing Urban Ecosystem Research Station.

\subsection{Data processing and statistical analysis}

Data were downloaded every day from the data logger. The $\mathrm{CO}_{2}$ concentrations from 1 min after the chamber closed and $20 \mathrm{sec}$ before the chamber opening were used to calculate the change in $\mathrm{CO}_{2}$ concentration, which is the slope of the linear regression of $\mathrm{CO}_{2}$ concentration and time when their correlation coefficient is larger than 0.95 . NEE was calculated by Eq. (1) (Davidson et al., 1998):

$F_{\mathrm{c}}=\mathrm{d} c / \mathrm{d} t \times V P / S R T$

where, $F_{\mathrm{c}}\left(\mu \mathrm{mol} /\left(\mathrm{m}^{2} \cdot \mathrm{sec}\right)\right)$ is the $\mathrm{CO}_{2}$ flux rate; $c$ ( $\mu \mathrm{mol} / \mathrm{mol})$ is the $\mathrm{CO}_{2}$ content, $\mathrm{d} c / \mathrm{d} t(\mu \mathrm{mol} /(\mathrm{mol} \cdot \mathrm{sec})$ is the change rate of $\mathrm{CO}_{2}$ concentrations; $V\left(\mathrm{~m}^{3}\right)$ is the volume of the chamber; $P(\mathrm{kPa})$ is the atmospheric pressure inside the chamber; $S\left(\mathrm{~m}^{2}\right)$ is the ground surface area enclosed by the chamber; $R\left(8.3 \times 10^{-3}\left(\mathrm{~m}^{3} \cdot \mathrm{kPa}\right) /(\mathrm{mol} \cdot \mathrm{K})\right)$ is the universal gas constant; $T(\mathrm{~K})$ is the air temperature inside the chamber.

The NEE was averaged for four measurements of four chambers. One way analysis of variance (ANOVA) was used to assess the effects of heating treatment on NEE. The statistical analyses were carried out using the SAS 8.0 software package (SAS Institute, Cary, North Carolina, USA).

Nocturnal NEE (the NEE when the PPFD $<100$ $\left.\mu \mathrm{mol} /\left(\mathrm{m}^{2} \cdot \mathrm{sec}\right)\right)$ and diurnal NEE (the NEE when the PPFD $\left.>100 \mu \mathrm{mol} /\left(\mathrm{m}^{2} \cdot \mathrm{sec}\right)\right)$ were separated to assess the NEE response to air temperature and PPFD. The relationship between the nocturnal NEE and soil temperature $\left(T_{\text {soil }}\right)$ is modeled by the following exponential Eq. (2):

$F_{\mathrm{c}}=b_{0} \times \exp \left(b T_{\text {soil }}\right)$

where, $b_{0}$ and $b$ are regression parameters. The temperature sensitivity of ecosystem respiration $\left(Q_{10}\right)$ can be estimated from parameter $b$ by Eq. (3):

$Q_{10}=\exp (10 b)$

The relationship between diurnal NEE and PPFD $\left(\mu \mathrm{mol} /\left(\mathrm{m}^{2} \cdot \mathrm{sec}\right)\right)$ can be modeled by following hyperbola Eq. (4):

$F_{\mathrm{c}}=R_{\text {eco }}-\left(A_{\max } \times \alpha \times \mathrm{PPFD}\right) \div\left(\alpha \times \mathrm{PPFD}+A_{\max }\right)$

where, $R_{\text {eco }}\left(\mathrm{mol} /\left(\mathrm{m}^{2} \cdot \mathrm{sec}\right)\right)$ is ecosystem respiration in daytime, $A_{\max }\left(\mu \mathrm{mol} /\left(\mathrm{m}^{2} \cdot \mathrm{sec}\right)\right)$ is the maximum NEE at infinite light, and $\alpha$ ( $\mu \mathrm{mol} \mathrm{CO}_{2} / \mu \mathrm{mol}$ photon) is the apparent quantum yield.

The above regression relationships were parameterized by bivariate regression analyses, including linear, hyperbola and exponential models using SigmaPlot 10.0 (Systat, San Jose, CA, USA).

\section{Results}

\subsection{Air and soil temperature}

In the period of the experiment, the average, maximum and minimum air temperature were $1.69^{\circ} \mathrm{C}, 16.67^{\circ} \mathrm{C}(21-\mathrm{Feb}-$ 2010), and $-9.06^{\circ} \mathrm{C}$ (17-Jan-2010), respectively (Table 1). The variation of air temperature is shown in Fig. 1.

The soil warming increased the soil temperature significantly $(p<0.0001)$. Soil temperature was increased

Table 1 Mean and range of air and soil temperature, photosynthetic photon flux density (PPFD), and diurnal, nocturnal and daily net ecosystem exchange (NEE) under heating treatment and control

\begin{tabular}{|c|c|c|c|c|}
\hline & \multicolumn{2}{|c|}{ Heating treatment } & \multicolumn{2}{|c|}{ Control } \\
\hline & Mean & Range & Mean & Range \\
\hline Air temperature $\left({ }^{\circ} \mathrm{C}\right)$ & 1.69 & $-9.06 \sim 16.67$ & 1.69 & $-9.06 \sim 16.67$ \\
\hline Soil temperature $\left({ }^{\circ} \mathrm{C}\right)$ & 8.41 & $16.22-2.65$ & 3.87 & $-0.73 \sim 16.19$ \\
\hline $\operatorname{PPFD}\left(\mathrm{mol} /\left(\mathrm{m}^{2} \cdot\right.\right.$ day $\left.)\right)$ & 13.43 & $31.16-1.63$ & 13.43 & $31.16-1.63$ \\
\hline Diurnal NEE $\left(\mu \mathrm{mol} /\left(\mathrm{m}^{2} \cdot \mathrm{sec}\right)\right)$ & -3.15 & $-7.57 \sim 0.09$ & -1.63 & $-6.27 \sim 0.65$ \\
\hline Nocturnal NEE $\left(\mu \mathrm{mol} /\left(\mathrm{m}^{2} \cdot \mathrm{sec}\right)\right)$ & 0.81 & $0.34-1.91$ & 1.08 & $0.31-2.97$ \\
\hline Daily NEE $\left(\mu \mathrm{mol} /\left(\mathrm{m}^{2} \cdot \mathrm{sec}\right)\right)$ & -0.71 & $-3.48 \sim 1.78$ & 0.13 & $-2.39 \sim 2.87$ \\
\hline
\end{tabular}



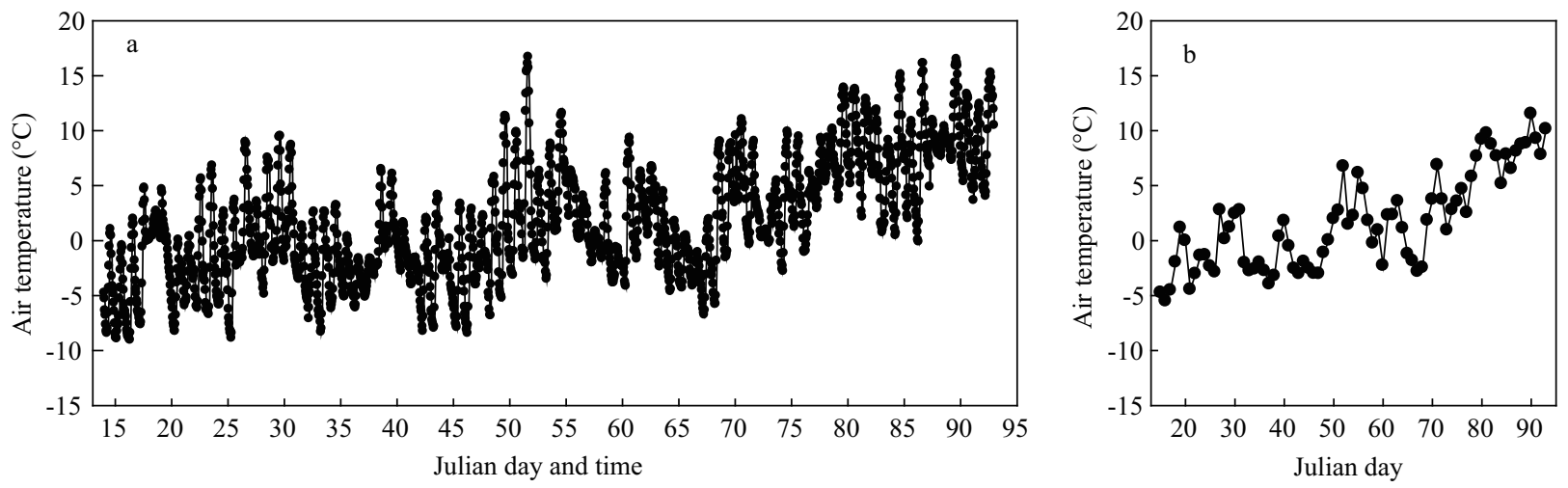

Fig. 1 Hourly averaged (a) and daily averaged (b) air temperature during the experiment period.

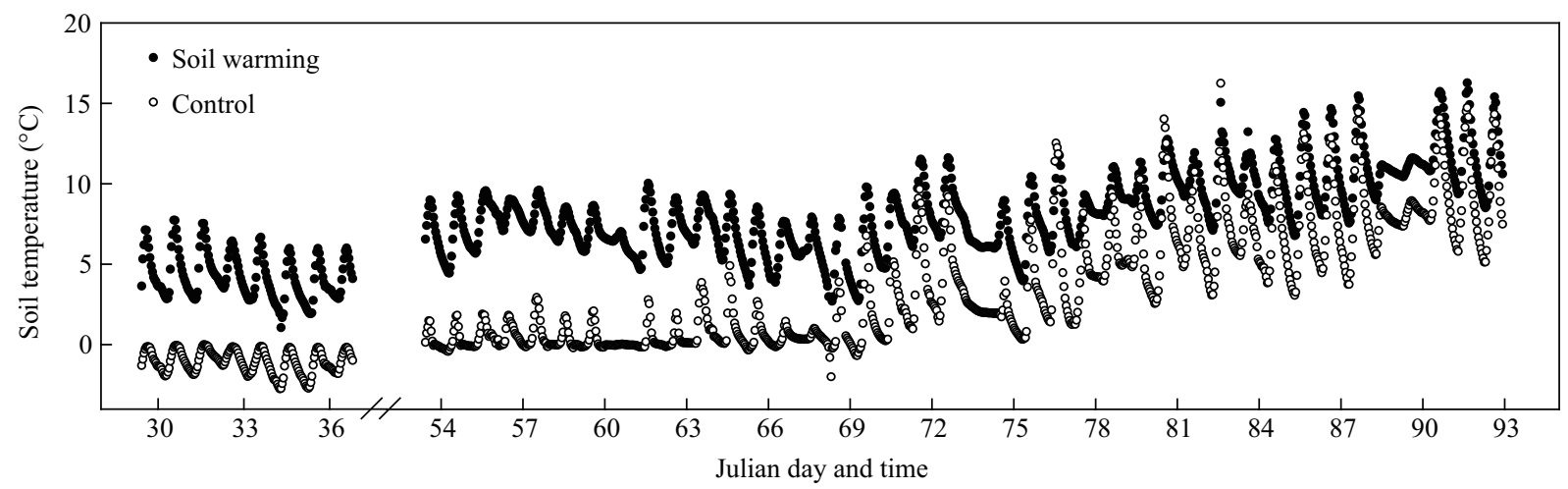

Fig. 2 Hourly soil temperature under control and soil warming regimes, the break (//) stands for the data missing period during DOY (day of year) $38-$ DOY 52.

by $4.7^{\circ} \mathrm{C}$ in average, $8.8^{\circ} \mathrm{C}$ in maximum and $0.02^{\circ} \mathrm{C}$ in minimum. The enhanced temperature declined with the air temperature rise (Fig. 2).

\subsection{Soil warming effect on NEE}

In the experimental period, significant diurnal variation in NEE occurred for both control and soil warming treatment and there were negative NEE in daytime, indicating carbon uptake by lawn regardless of soil warming or not (Fig. 3). On daily scale, nearly all NEE under soil warming treatment were negative except few cloud or raining days while NEE under control transformed from source to sink on DOY (the day of year) 74 (15-Mar-2010) (Fig. 4a). In either diurnal (Fig. 4b), or nocturnal (Fig. 4c) scale, NEE under soil warming treatment were lower than that under control significantly $(p<0.0001)$.
The average daily NEE and diurnal NEE were significantly decreased by the soil warming treatment ( $p$ $<0.0001)$. The average NEE under the soil warming treatment was $-0.71 \mu \mathrm{mol} /\left(\mathrm{m}^{2} \cdot \mathrm{sec}\right)$, it indicated that the lawn ecosystem was a $\mathrm{CO}_{2}$ sink under the warming treatment. The lawn ecosystem under the control was a $\mathrm{CO}_{2}$ source $\left(0.13 \mu \mathrm{mol} /\left(\mathrm{m}^{2} \cdot \mathrm{sec}\right)\right)$ (Table 1$)$. The average diurnal NEE under heating treatment was -3.15 $\mu \mathrm{mol} /\left(\mathrm{m}^{2} \cdot \mathrm{sec}\right)$, which was about two times of control $\left(-1.63 \mu \mathrm{mol} /\left(\mathrm{m}^{2} \cdot \mathrm{sec}\right)\right)$ (Table 1$)$, indicated that heating treatment increased the $\mathrm{CO}_{2}$ uptake. The average nocturnal $\mathrm{NEE}$ was $0.81 \mu \mathrm{mol} /\left(\mathrm{m}^{2} \cdot \mathrm{sec}\right)$ under heating treatment, the average nocturnal NEE was $1.08 \mu \mathrm{mol} /\left(\mathrm{m}^{2} \cdot \mathrm{sec}\right)$ under the control, The difference between the nocturnal NEE under the soil warming treatment and control was not significant (Table 1).

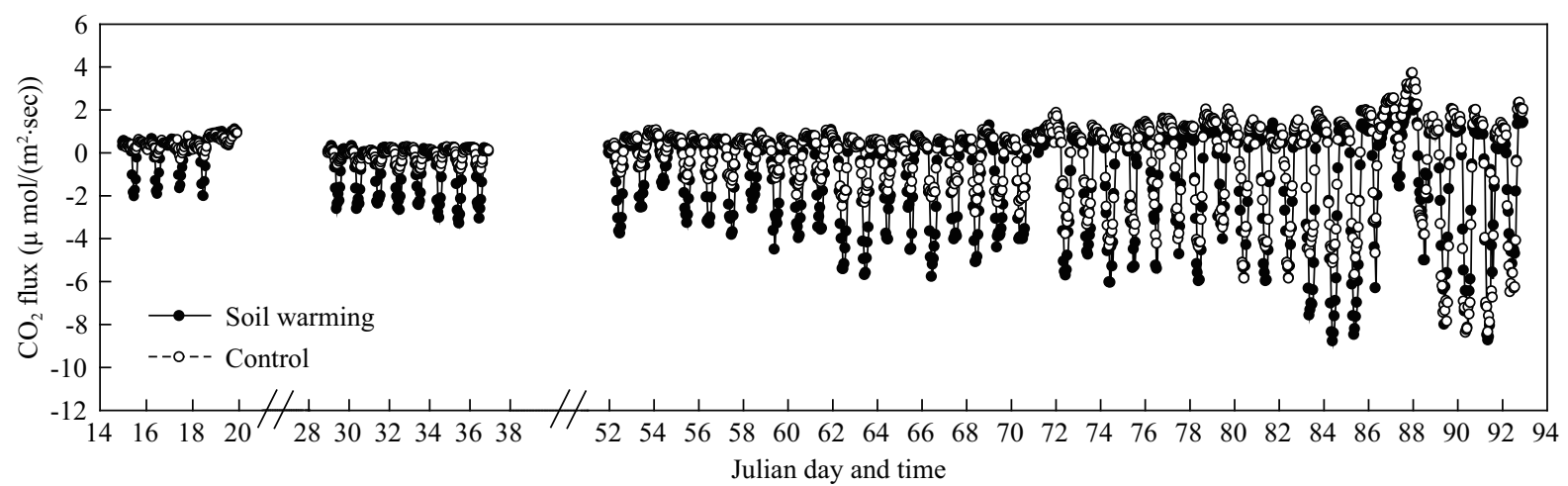

Fig. 3 Hourly $\mathrm{CO}_{2}$ flux between atmosphere and lawn ecosystem under control and soil warming regimes, the breaks $(/ /)$ stand for the data missing periods during DOY $20-28$ and DOY $38-52$. 


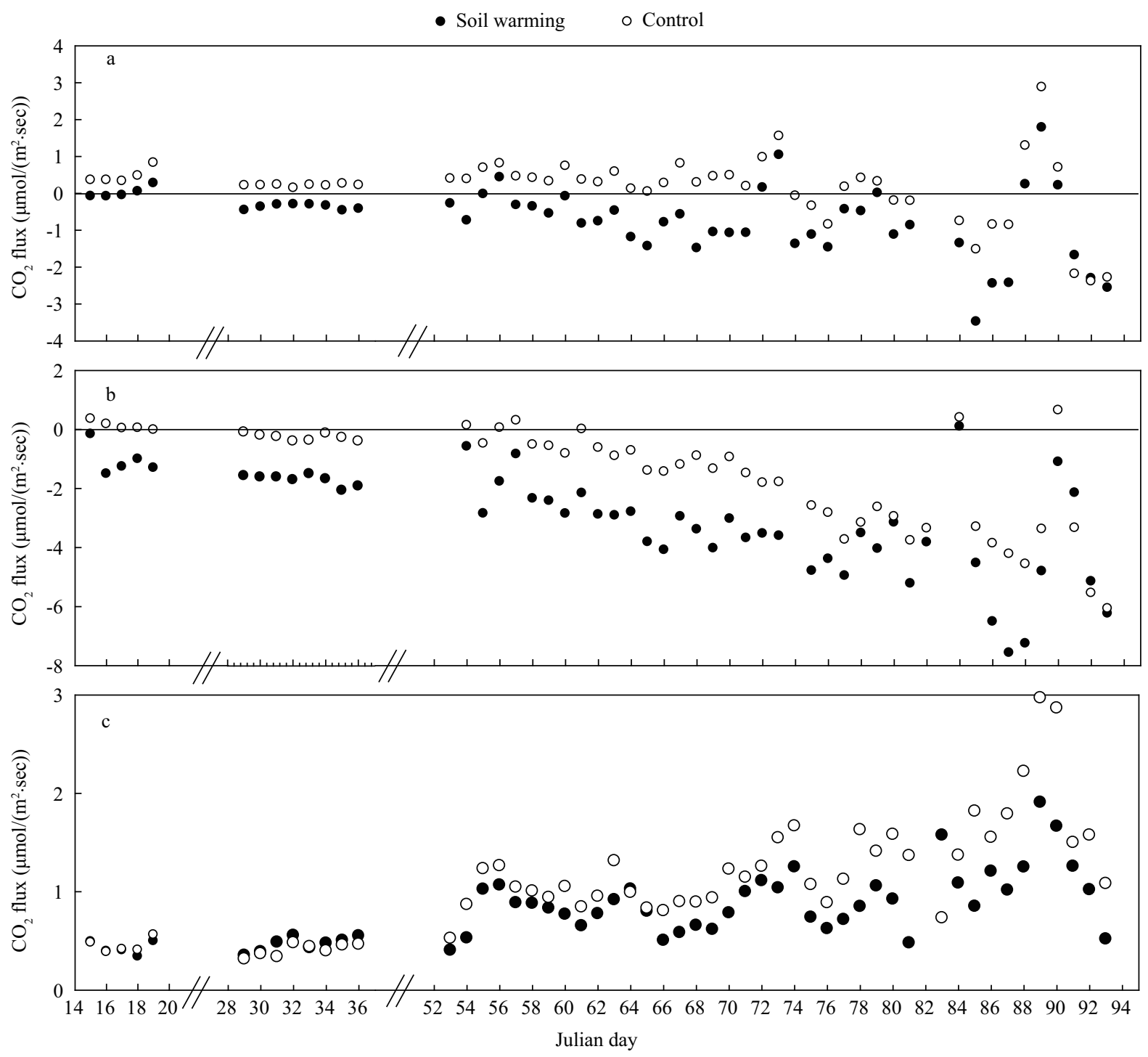

Fig. 4 Effect of soil warming on daily (a), diurnal (b) and nocturnal (c) $\mathrm{CO}_{2}$ flux between atmosphere and lawn ecosystem ( $n=51$ ) that was without warming (control) compared to soil warming treatment (soil warming), the breaks $(/ /$ ) stand for the data missing periods during DOY $20-28$ and DOY 38-52.

\subsection{Relationships of NEE to soil temperature and PPFD}

There were significant exponential relationships between nocturnal NEE and soil temperature under both heating treatment $\left(R^{2}=0.43, P<0.0001\right)$ and the control $\left(R^{2}\right.$ $=0.35, P<0.0001)$ (Fig. 5). The soil temperature sensitivities of nocturnal NEE $\left(Q_{10}\right)$ was 3.86 under heating treatment, which only $54 \%$ of that under the control $\left(Q_{10}\right.$ $=7.03$ ).

The diurnal NEE decreased with the increased PPFD under both heating treatment and the control during the study period (Fig. 6). Although the correlations between diurnal NEE and PPFD were well fit with the rectangular hyperbola functions, the correlation coefficient under heating treatment $\left(R^{2}=0.68\right)$ was larger than that under the control $\left(R^{2}=0.44\right)$, the parameters $\alpha$ and $A_{\max }$ under heating treatment were $0.05 \mu \mathrm{mol} \mathrm{CO} / \mu \mathrm{mol}$ photon and $7.21 \mu \mathrm{mol} /\left(\mathrm{m}^{2} \cdot \mathrm{sec}\right)$, respectively, and nearly doubled that of control $\left(\alpha=0.03 \mu \mathrm{mol} \mathrm{CO} / \mu \mathrm{mol}\right.$ photon, $A_{\max }=3.50$ $\left.\mu \mathrm{mol} /\left(\mathrm{m}^{2} \cdot \mathrm{sec}\right)\right)$.

\section{Discussion}

\subsection{Lawn NEE during the transition period from win- ter to spring}

In the experiment period, the daily NEE under control was $0.44-1.55 \mu \mathrm{mol} /\left(\mathrm{m}^{2} \cdot \mathrm{sec}\right)$ before 1-Mar-2010, indicating the lawn ecosystem was a carbon source with $0.37 \mu \mathrm{mol} /\left(\mathrm{m}^{2} \cdot \mathrm{sec}\right)\left(1.41 \mathrm{~g} \mathrm{CO}_{2} /\left(\mathrm{m}^{2} \cdot\right.\right.$ day $\left.)\right)$ in winter, even though it absorbed $\mathrm{CO}_{2}$ at the daytime. This result was well within the range of similar ecosystem, such as humid-temperate pastures $\left(2.88 \mathrm{~g} \mathrm{CO}_{2} /\left(\mathrm{m}^{2}\right.\right.$.day $)$; Skinner, 2007) and sagebrush-steppe ecosystems (0.68-1.31. CO $\mathrm{CO}_{2} /$ $\left(\mathrm{m}^{2}\right.$.day); Gilmanov et al., 2004).

Regehr and Bazzaz (1976) suggested two possible photosynthetic acclimation strategies for over-wintering plants: limiting the photosynthesis with completely dormancy during the winter months or keeping photosynthetic capacity during winter time when the climate conditions were favorable for $\mathrm{CO}_{2}$ uptake. The study of Kato et 

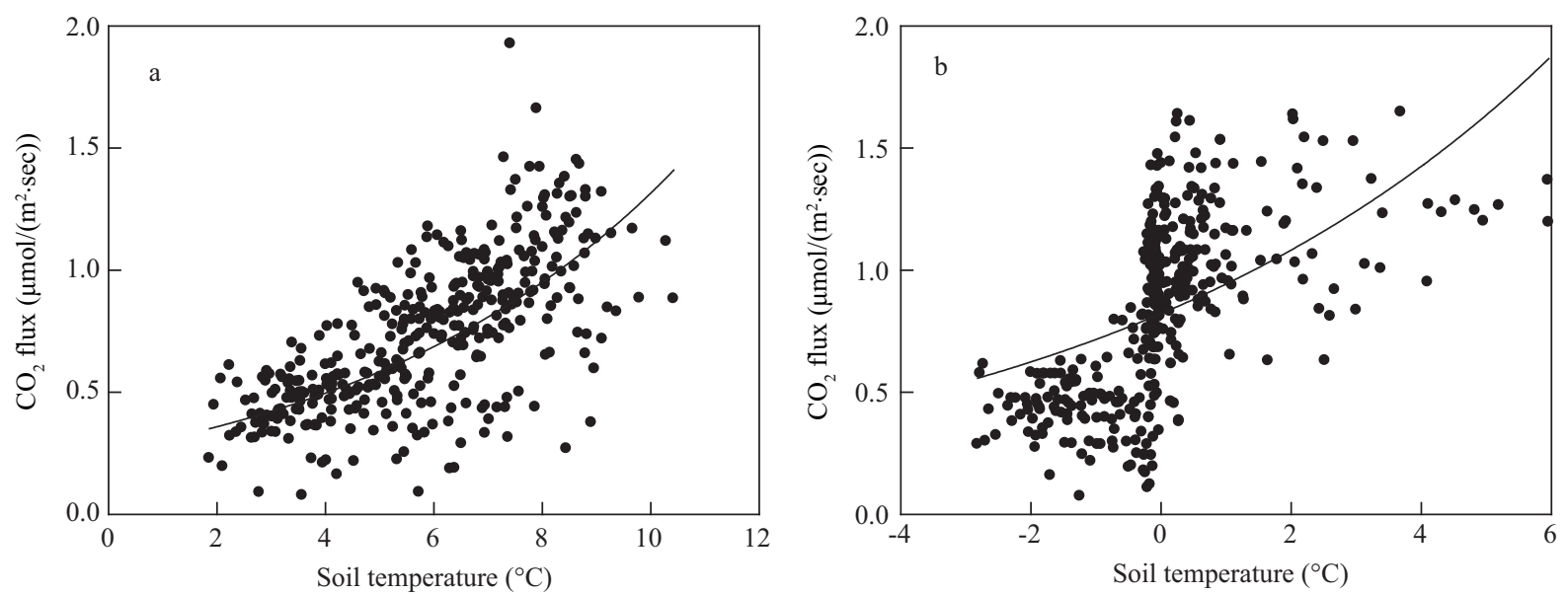

Fig. 5 Relationship between nighttime $\mathrm{CO}_{2}$ fluxes and soil temperature under soil warming treatment (a) and control (b). Soil warming treatment: $F \mathrm{c}$ $=0.328 \times \exp (0.135 T) ; R^{2}=0.43 ; P<0.0001$. Control: $F \mathrm{c}=0.841 \times \exp (0.195 T), R^{2}=0.35, P<0.0001$.
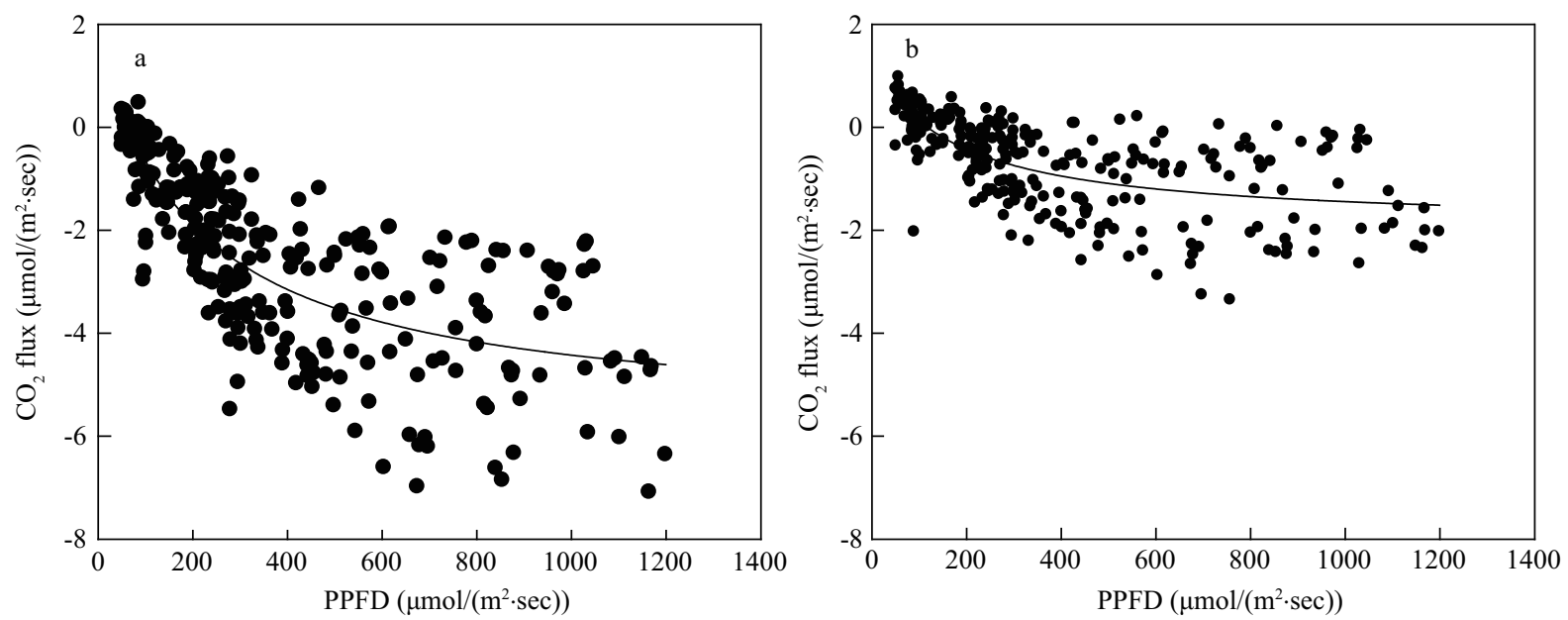

Fig. 6 Relationships between daytime $\mathrm{CO}_{2}$ fluxes and PPFD (photosynthetic photon flux density) under soil warming treatment (a) and control (b). Soil warming treatment: $F_{\mathrm{c}}=2.18-(0.05 \times 7.72 \times \mathrm{PPFD}) \div(0.05 \times \mathrm{PPFD}+7.72) ; R^{2}=0.68, p<0.0001$. Control: $F_{\mathrm{c}}=1.65-(0.03 \times 3.50 \times \mathrm{PPFD})$ $\div(0.03 \times \mathrm{PPFD}+3.50) ; R^{2}=0.44 ; p<0.0001$

al. (2005) has indicated that no photosynthesis could be detected during winter under Kobresia meadow ecosystem on the Qinghai-Tibetan plateau. Yang et al. (2008) reported that the daytime NEE of the Stipa krylovii steppe ecosystem in Inner Mongolia was positive and larger than night in winter period. The lawn ecosystem of this study adapt to winter by the latter acclimation strategies of Regehr and Bazzaz, which indicated by the negative NEE detected during daytime irrespective of heating or not since DOY 16 (Fig. 3). The similar result that photosynthesis commenced 1.5 months before soil temperatures above $0^{\circ} \mathrm{C}$ in the boreal forest (Tanja et al., 2003). Different ecosystems have different minimum air temperatures for photosynthesis. Pisek (1973) reported that the range for air temperate evergreen tree species varied from -4 to $-8^{\circ} \mathrm{C}$. Skinner (2007) reported that the photosynthesis could occur in temperate grasses at the air temperature about $-4^{\circ} \mathrm{C}$, even the grasses underwent the night low air temperature about $-11^{\circ} \mathrm{C}$. Larsen et al. (2007) reported that subarctic heath ecosystem kept photosynthetic capacity during whole winter. In this study, the lawn ecosystem kept photosynthetic capacity during whole experiment period, with the minimum air temperature $-9.1^{\circ} \mathrm{C}$. The $\mathrm{CO}_{2}$ uptake is mainly controlled by PPFD, which have been extensively confirmed. In our study, the correlations between diurnal NEE and PPFD were well fit using the rectangular hyperbola functions, and the regressive parameters $\alpha$ and $A_{\max }$ were increased with increasing temperature and development of the lawn.

The nocturnal NEE, i.e., ecosystem respiration, were averaged to be $1.08 \mu \mathrm{mol} /\left(\mathrm{m}^{2} \cdot \mathrm{sec}\right)$, which was lower than soil respirations of urban lawn reported in Shanghai (1.16$\left.5.95 \mu \mathrm{mol} /\left(\mathrm{m}^{2} \cdot \mathrm{sec}\right)\right)$ and Fuzhou $\left(0.85-7.4 \mu \mathrm{mol} /\left(\mathrm{m}^{2} \cdot \mathrm{sec}\right)\right.$; Sun et al., 2009). This discrepancy may be due to the higher temperature in those Chinese cities than that in Beijing.

The transition from winter to spring has been considered as critical period influencing ecosystem carbon cycle, especially for soil respiration, when the soil was in daily freeze-thaw cycle. In this study, the nocturnal NEE increased significantly in later period of the experiment, especially after March 15, due to soil freeze-thaw cycle. The rapid increase of $\mathrm{CO}_{2}$ efflux during freeze-thaw cycle has also been found in tundra heath ecosystem (Elberling et al., 2003) and forest ecosystem (Hubbard et al., 2005; Schindlbacher et al., 2007). The increase of root and microbial activity resulted from the soil temperature rise and free water availability would stimulate the rapid increase 
of $\mathrm{CO}_{2}$ effluxes (Ostroumov and Siegert, 1996; Hanson et al., 2003).

The temperature was the most important factor that drives NEE of ecosystem. There were significant exponential relationships between nocturnal NEE and soil temperature considering whole experiment period $\left(R^{2}=\right.$ $0.35, P<0.0001$ ) (Fig. 5), however, the further analysis indicated that no obvious relationship occurred between winter soil $\mathrm{CO}_{2}$ efflux and soil temperature when soil temperature lower than $-0.5^{\circ} \mathrm{C}$ (data not showed here). This result was consistent with the report that soil temperature had no direct effect on soil respiration in winter (Wang et al., 2010).

\subsection{Feedback of winter NEE to climate change}

The positive feedback of terrestrial ecosystem to climate warming means that the warming increased the carbon release from ecosystem and the negative feedback means that the warming increased the carbon storage in ecosystems (Luo, 2007). The response of carbon flux to climate warming varied and depended mainly on which climatological factor was the limiting factor of plant growth to the ecosystem (Boeck et al., 2007). The climate warming could benefit to the plant metabolic activity that was limited by the low temperatures in winter time and in polar regions (Marchand et al., 2004), but aggravate the heat and drought stress and then decrease the photosynthetic capacity of the ecosystem in warmer and drier climate condition (Arnone et al., 2008; Llorens et al., 2003). The difference of the responses of the gross primary productivity (GPP) and ecosystem respiration to climate warming resulted in the complexity of effect of climate warming on NEE. Kharin and Zwiers (2000) reported that the increase of air temperature at night was larger than day, this could resulted in that the increase of ecosystem respiration was larger than GPP, and the increase of GPP would be limited by the lower PPFD in winter (Welp et al., 2007). However, our results showed that $\mathrm{CO}_{2}$ uptake of lawn ecosystem increased and the ecosystem respiration had less response to warming, and the NEE showed a negative feedback on climate change during the transition period from winter to spring. Similar results were also observed in other warming experiments. An analysis of a decade of eddy covariance data from six European forests stands indicated that the GPP was the maximum in a exceptionally warm spring, the ecosystem respiration was less anomalous to climate warming, and the net uptake in warm spring was larger than the long term mean uptake (Delpierre et al., 2009). Huxman et al. (2003) reported that climate warming increased the photosynthesis of a subalpine, coniferous forest during spring, but the ecosystem respiration was not increased significantly leading to the increase of $\mathrm{CO}_{2}$ uptake. The similar result was observed in tundra during spring in a low Arctic tundra (Lafleur and Humphreys, 2008). The GPP was increased by the climate warming through increasing the photosynthetic capacity and the lengthening the growing season (Welker et al., 2004; Berninger, 1997; Randerson et al., 1999; Idso et al., 2000; White et al., 2000; Saxe et al., 2001), which defined by the first continuous 3-day period of net carbon uptake (Welp et al., 2007), but the winter and spring climate warming was not always increased the growing season, for example, Yu et al. (2001) reported that the dormancy period of a alpine meadow in Tibetan Plateau was lengthened by the continued winter warming.

Our study indicated that warming increased the $\alpha$ and $A_{\text {max }}$ by about 2 times, which stimulate $\mathrm{CO}_{2}$ uptake of the lawn. The onset of the growing season for the control was on DOY 74, but the lawn ecosystem under warming was net carbon uptake during almost the whole experiment period. Welker et al. (2004) reported that the growing season was increased by 2 weeks and the gross ecosystem productivity was increased by the warming. Previous study indicated that GPP was reduced by the climate warming due to climate warming resulting in drought stress and reduction in photosynthetic capacity, and ecosystem respiration was increased by climate warming (Zhou et al., 2010). In our study, the lawn was irrigated before winter, so no water stress was observed. The global warming stimulated plant growth and increased the photosynthetic capacity and GPP.

No significant ecosystem respiration difference was found between the warming treatment and control. In lawn, the biomass accumulation was moved away from the ecosystem by grass mowing, which would decrease the grass litter and soil labile carbon content (Luo et al., 2009), this might be one of the reasons of no heating effect on the ecosystem respiration. Bokhorst et al. (2010) suggest that winter warming events do not affect fresh litter decomposition in a sub-Arctic heath land. On the other hand, the soil would undergo the froze-thaw cycle in later winter, and induce more $\mathrm{CO}_{2}$ emission, but this would not occur in heating treatment lawn. The $Q_{10}$ was decreased by heating treatment that would lead to the decrease of ecosystem respiration.

\section{Conclusions}

The present study investigated the lawn NEE and its response to climate warming during the transition period from winter to spring. Lawn ecosystem provided a negative feedback to climate warming. Lawn photosynthesis was consistently stimulated by warming almost the whole experiment period, $A_{\max }$ and $\alpha$ under the warming treatment were about 2 times compared to the control. But the ecosystem respiration had no significant difference in response to heating treatment, which would be attributed to less lawn litter and soil labile carbon content due to lawn mowing. Heating treatment speeded up the lawn ecosystem converting from a $\mathrm{CO}_{2}$ source to a $\mathrm{CO}_{2}$ sink in early spring and lengthened the growing season of lawn ecosystem. The daily NEE were negative under heating treatment in winter, suggesting that the winter photosynthesis should not be ignored, especially under climate warming. In urban ecosystems, the compounding effects of management measures (irrigation, clipping, fertilization, etc.) and climate change on ecosystem carbon cycle need more investigation to provide more information for decision makers to achieve 
urban sustainable development.

\section{Acknowledgments}

This work was supported by the National Natural Science Foundation of China (No. 41030744, 31170424) and the Chinese Academy of Sciences for Strategic Priority Research Program (No. XDA05050602, XDA05060102). The experimental site was provided by Beijing Botanic Garden for Education.

\section{References}

Allaire S E, Dufour-L'Arrivée C, Lafond J A, Lalancette R, Brodeur J, 2008. Carbon dioxide emissions by urban turfgrass areas. Canadian Journal of Soil Science, 88(4): 529-532.

Amthor J S, 1994. Scaling $\mathrm{CO}_{2}$ photosynthesis relationships from the leaf to the canopy. Photosynthesis Research, 39(3): 321350.

Arnone III J A, Verburg P S J, Johnson D W, Larsen J D, Jasoni R L, Lucchesi A J et al., 2008. Prolonged suppression of ecosystem carbon dioxide uptake after an anomalously warm year. Nature, 455(7211): 383-386.

Baldocchi D D, Wilson K B, 2001. Modeling $\mathrm{CO}_{2}$ and water vapor exchange of a temperate broadleaved forest across hourly to decadal time scales. Ecological Modelling, 142(12): $155-184$.

Berninger F, 1997. Effects of drought and phenology on GPP in Pinus sylvestris: a simulation study along a geographical gradient. Functional Ecology, 11(1): 33-42.

Boeck H J D, Lemmens C M H M, Vicca S, Berge J V, Dongen S V, Janssens I A et al., 2007. How do climate warming and species richness affect $\mathrm{CO}_{2}$ fluxes in experimental grasslands? New Phytologist, 175(3): 512-522.

Bokhorst S, Bjerke J W, Melillo J, Callaghan T V, Phoenix G K, 2010. Impacts of extreme winter warming events on litter decomposition in a sub-Arctic heath land. Soil Biology $\mathcal{F}$ Biochemistry, 42(4): 611-617.

Bronson D R, Gower S T, 2010. Ecosystem warming does not affect photosynthesis or aboveground autotrophic respiration for boreal black spruce. Tree Physiology, 30(4): 441-449.

Davidson E A, Belk E, Boone R D, 1998. Soil water content and temperature as independent or confounded factors controlling soil respiration in a temperate mixed hardwood forest. Global Change Biology, 4(2): 217-227.

Delpierre N, Soudanik K, François C, Köstner B, Pontailler J Y, Nikinmaa E et al., 2009. Exceptional carbon uptake in European forests during the warm spring of 2007: a datamodel analysis. Global Change Biology, 15(6): 1455-1474.

Elberling B, Brandy K K, 2003. Uncoupling of microbial $\mathrm{CO}_{2}$ production and release in frozen soil and its implications for field studies of arctic C cycling. Soil Biology and Biochemistry, 35(2): 263-272.

Ensminger I, Sveshnikov D, Campbell D A, Funk C, Jansson S, Lloyd J et al., 2004. Intermittent low temperatures constrain spring recovery of photosynthesis in boreal Scots pine forests. Global Change Biology, 10(6): 995-1008.

Gilmanov T G, Johnson D A, Saliendra N Z, Svejcar T J, Angell R F, Clawson K L, 2004. Winter $\mathrm{CO}_{2}$ fluxes above sagebrush-steppe ecosystems in Idaho and Oregon. Agricultural and Forest Meteorology, 126(1-2): 73-88.

Goulden M L, Wofsy S C, Harden J W, Trumbore S E, Crill P M, Grill P M et al., 1998. Sensitivity of boreal forest carbon balance to soil thaw. Science, 279(5348): 214-217.

Griffis T J, Black T A, Gaumont-Guay D, Drewitt G B, Nesic Z, Barr A G et al., 2004. Seasonal variation and partitioning of ecosystem respiration in a southern boreal aspen forest. Agricultural and Forest Meteorology, 125(3-4): 207-223.

Hanson P J, O’Neill E G, Chambers M L S, Riggs J S, Joslin J D, Wolfe M H, 2003. Soil respiration and litter decomposition. In: North American Temperate Deciduous Forest Responses to Changing Precipitation Regimes (Hanson P J, Wullschleger S D, eds.). Springer-Verlag, New York. 163189.

Hubbard R M, Ryan M G, Elder K, Rhodes C C, 2005. Seasonal patterns in soil surface $\mathrm{CO}_{2}$ flux under snow cover in 50 and 300 year old subalpine forests. Biogeochemistry, 73(1): 93-107.

Huxman T E, Turnipseed A A, Sparks J P, Harley P C, Monson $\mathrm{R} \mathrm{K}, 2003$. Temperature as a control over ecosystem $\mathrm{CO}_{2}$ fluxes in a high-elevation, subalpine forest. Oecologia, 134(4): 537-546.

Idso C D, Idso S B, Kimball B A, Park H S, Hoober J K, Balling J R C, 2000. Ultra-enhanced spring branch growth in $\mathrm{CO}_{2}$ enriched trees: can it alter the phase of the atmospheres seasonal $\mathrm{CO}_{2}$ cycle? Environmental and Experimental Botany, 43(2): 91-100.

IPCC (Intergovernmental Panel on Climate Change), 2000. Land use, land-use change, and forestry (including summary for policymakers, which is available in Arabic, Chinese, English, French, Russian and Spanish). A Special Report of the IPCC, 2000.

IPCC (Intergovernmental Panel on Climate Change), 2007. Contribution of working group III to the fourth assessment report of the intergovernmental panel on climate change. In: Climate Change in 2007: Mitigation (Metz B, Davidson O R, Bosch P R et al., eds.). Cambridge University Press, Cambridge, UK.

Kato T, Hirota M, Tang Y H, Cui X Y, Li Y N, Zhao X $\mathrm{Q}$ et al., 2005. Strong temperature dependence and no moss photosynthesis in winter $\mathrm{CO}_{2}$ flux for a Kobresia meadow on the Qinghai-Tibetan plateau. Soil Biology and Biochemistry, 37(10): 1966-1969.

Kharin V V, Zwiers F W, 2000. Changes in the extremes in an ensemble of transient climate simulations with a coupled atmosphere-ocean GCM. Journal of Climate, 13(21): 37603788.

Keeling R F, Piper S C, Heimann M, 1996. Global and hemispheric $\mathrm{CO}_{2}$ sinks deduced from changes in atmospheric $\mathrm{O}_{2}$ concentration. Nature, 381: 218-221.

Lafleur P M, Humphreys E R, 2008. Spring warming and carbon dioxide exchange over low Arctic tundra in central Canada. Global Change Biology, 14(4): 740-756.

Lao X R, 2002. Nutrition and Fertilization on Lawn. China Agricultural Press, Beijing, China.

Larsen K S, Ibrom A, Jonasson S, Michelsen A, Beier C, 2007. Significance of cold-season respiration and photosynthesis in a subarctic heath ecosystem in Northern Sweden. Global Change Biology, 13(7): 1498-1508.

Law B E, Williams M, Anthoni P M, Baldocchi D D, Unsworth M H, 2000. Measuring and modeling seasonal variation of carbon dioxide and water vapour exchange of a Pinus ponderosa forest subject to soil water deficit. Global Change Biology, 6(6): 613-630.

Llorens L, Penuelas J, Estiarte M, 2003. Ecophysiological responses of two Mediterranean shrubs, Erica multiflora and Globularia alypum, to experimentally drier and warmer 
conditions. Physiologia Plantarum, 119(2): 231-243.

Lloyd J, Langenfelds R L, Francey R J, Gloor M, Tchebakova N M, Zolotoukhine D et al., 2002. A trace gas climatology above Zotino, central Siberia. Tellus Series B-Chemical and Physical Meteorology, 54(5): 749-767.

Luo Y Q, 2007. Terrestrial carbon-cycle feedback to climate warming. Annual Review of Ecology, Evolution and Systematics, 38(1): 683-712.

Luo Y Q, Sherry R, Zhou X H, Wan S Q, 2009. Terrestrial carboncycle feedback to climate warming: experimental evidence on plant regulation and impacts of biofuel feedstock harvest. Global Change Biology Bioenergy, 1(1): 62-74.

Marchand F L, Nijs I, De Boeck H J, Kockelbergh F, Mertens S, Beyens L, 2004. Increased turnover but little change in the carbon balance of higharctic tundra exposed to whole growing season warming. Arctic, Antarctic and Alpine Research, 36(3): 298-307.

Mimet A, Pellissier V, Quénol H, Aguejdad R, Dubreuil V, Rozé F, 2009. Urbanisation induces early flowering: evidence from Platanus acerifolia and Prunus cerasus. International Journal of Biometeorology, 53(3): 287-298.

Monson R K, Sparks J P, Rosenstiel T N, Scott-Denton L E, Huxman T E, Harley P C et al., 2005. Climatic influences on net ecosystem $\mathrm{CO}_{2}$ exchange during the transition from wintertime carbon source to springtime carbon sink in a high-elevation, subalpine forest. Oecologia, 146(1): 130 147.

Monson R K, Turnipseed A A, Sparks J P, Harley P C, ScottDenton L E, Sparks K et al., 2002. Carbon sequestration in a high-elevation, subalpine forest. Global Change Biology, 8(5): 459-478.

Ostroumov V E, Siegert C, 1996. Exobiological aspects of mass transfer in microzones of permafrost deposits. Advances in Space Research, 18(12): 79-86.

Pisek A, 1973. Effect of temperature on metabolic processes. 1. Photosynthesis. In: Temperature and Life (Precht H, Chrlstophersen J, Hensel H, Larcher W, eds.). SpringerVerlag, Berlin, Germany. 102-127.

Qian Y L, Follett R F, 2002. Assessing soil carbon sequestration in turfgrass systems using long-term soil testing data. Agronomy Journal, 94(4): 930-935.

Ranajit S, 2008. Technical assessment of the carbon sequestration potential of managed turfgrass in the United States. http://www.opei.org/dotAsset/15570.pdf.

Randerson J T, Field C B, Fung I Y, Tans P P, 1999. Increases in early season ecosystem uptake explain recent changes in the seasonal cycle of atmospheric $\mathrm{CO}_{2}$ at high northern latitudes. Geophysical Research Letters, 26(17): 27652768.

Regehr D L, Bazzaz F A, 1976. Low temperature photosynthesis in successional winter annuals. Ecology, 57(6): 1297-1303.

Ryan M G, 1991. Effects of climate change on plant respiration. Ecological Application, 1(2): 157-167.

Ryan M G, Gower S T, Hubbard R M, Waring R H, Gholz H L, Cropper J W R et al., 1995. Woody tissue maintenance respiration of four conifers in contrasting climates. Oecologia, 101(2): 133-140.

Ryan M G, Hunter E, McMurtrie R, Agren G, Aber J, Friend A et al., 1996. Comparing models of ecosystem function for temperate conifer forests. In: Global Change: Effects on Coniferous Forests and Grasslands (Greymeyer A I, Hall D O, Agren G I, Melillo J M, eds.). John Wiley, New York, USA. 313-361.
Saxe H, Cannell M G R, Johnsen O, Ryan M G, Vourlitis G, 2001. Tree and forest functioning in response to global warming. New Phytologist, 149(3): 369-399.

Schindlbacher A, Zechmeister-Boltenstern S, Glatzel G, Jandl R, 2007. Winter soil respiration from an Austrian mountain forest. Agricultural and Forest Meteorology, 146(3-4): 205215.

Skinner R H, 2007. Winter carbon dioxide fluxes in humidtemperate pastures. Agricultural and Forest Meteorology, 144(1-2): 32-43.

Sun Q, Fang H L, Liu M, Liang J, Hao R, 2009. The winter soil respiration characteristics and its influencing factors on typical urban plant community in Shanghai. Journal of Shanghai Jiaotong University, Agricultural Science, 27(3): 231-234.

Tanja S, Berninger F, Vesala T, Markkanen T, Hari P, Mäkelä A et al., 2003. Air temperature triggers the recovery of evergreen boreal forest photosynthesis in spring. Global Change Biology, 9(10): 1410-1426.

Teodorescu G, 2010. Climate change impact on urban ecosystems and sustainabledevelopment of cities in Romania. WSEAS Transactions on Environment and Development, 2(6): 103112.

Vemap M, 1995. Vegetation ecosystem modeling and analysis project: Comparing biogeography and biogeochemistry models in a continental-scale of terrestrial ecosystem response to climate change and $\mathrm{CO}_{2}$ doubling. Global Biogeochemical Cycles, 9(4): 407-437.

Wang W, Peng S S, Wang T, Fang J Y, 2010. Winter soil $\mathrm{CO}_{2}$ efflux and its contribution to annual soil respiration in different ecosystems of a forest-steppe ecotone, North China. Soil Biology $\mathcal{E}$ Biochemistry, 42(3): 451-458.

Welker J M, Fahnestock J T, Henry G H R, O’Dea K W, Chimner R A, 2004. $\mathrm{CO}_{2}$ exchange in three Canadian High Arctic ecosystems: response to long-term experimental warming. Global Change Biology, 10(12): 1981-1995.

Welp L R, Randerson J T, Liu H, 2007. The sensitivity of carbon fluxes to spring warming and summer drought depends on plant functional type in boreal forest ecosystems. Agricultural and Forest Meteorology, 147(3-4): 172-185.

White A, Cannell M G R, Friend A D, 2000. The high latitude terrestrial carbon sink: a model analysis. Global Change Biology, 6(2): 227-245.

World Resources Institute, 1996. World Resources: A Guide to the Global Environment. Oxford University Press, New York.

Yang J, Zhou G S, Wang Y L, Wang Y H, 2008. Characteristics of net ecosystem flux exchanges over Stipa krylovvi steppe in Inner Mongolia. Chinese Journal of Applied Ecology, 19(3): 533-538.

Yin H J, Liu Q, Lai T, 2008. Warming effects on growth and physiology in the seedlings of the two conifers Picea asperata and Abies faxoniana under two contrasting light conditions. Ecological Research, 23: 459-469.

Yu H Y, Lauedeling E, Xu J C, 2010. Winter and spring warming result in delayed spring phenology on the Tibetan Plateau. Proceedings of the National Academy of Sciences of the United States of America, 107(51): 22151-22156.

Zhou X H, Luo Y Q, Gao C, Verburg P S J, Arnone III J A, Darrouzet-Nardi A et al., 2010. Concurrent and lagged impacts of an anomalously warm year on autotrophic and heterotrophic components of soil respiration: a deconvolution analysis. New Phytologist, 187(1): 184-198. 